\title{
Analisis Pengaruh Kompetensi Terhadap Kinerja Pegawai Satuan Polisi Pamong Praja Kota Pontianak
}

\author{
PARWIDI \\ DR. MUNTAHA, MM \\ STIE Boedi Oetomo \\ Jl. Ampera, No. GG 1-2 Kota Baru, Pontianak \\ Email: stie_boedioetomo@yahoo.co.id
}

\section{Diterima 4 September 2018; disetujui 2 November 2018;}

\begin{abstract}
Competence is a behavior that more emphasis on productive behavior that must be owned and done by someone in carrying out an activity in order to excel outstanding. Performance of a person related to the level of success in doing something work in accordance with the field of duty in order to achieve organizational goals. Psychologically, a person's abilities consist of the potential ability and the ability of reality. Therefore the Pontianak Municipal Police Prison Unit should be able to demonstrate its superiority through its competence in order to improve the performance of human resources. Thus expected employees can give the best contribution through the competence held for the achievement of good performance, so as to meet the target and the target work of individuals who are given and contribute to the success of achieving the target organization Pontianak City Pamong Praja Police Unit as a whole. The problem in this research is how the influence of competence to the performance of personnel of Police Unit of Pontianak Municipal Police?. Research Methods in the form of a survey, with a population of all employees at the Pontianak Municipal Police Service Unit of 110 people. Sampling using Census method. Data analysis using Multiple Linear Regression Multiple Linear Regression. The results of simultaneous research competence that includes knowledge, skills and individual behavior affect the performance. Partially knowledge and skills have an effect on to performance while individual behavior has no effect.
\end{abstract}

Keywords: Human Resources, Competencies and Performance

\section{PENDAHULUAN}

Pentingnya keberadaan sumber daya manusia dalam organisasi berawal dari semakin diperlukannya fungsi sumber daya manusia untuk pelaksanaan dan pengembangan organisasi. Seiring dengan itu kegiatan sumber daya manusia terus berkembang, yaitu dari kegiatan yang bersifat administratif kearah bersifat manajerial dan strategis. Perlu diketahui diketahui bahwa penerapan kompetensi tidak dapat dipisahkan dari kemampuan seseorang di dalam menggunakan pemikiran intelektual (kognitif) dan mengendalikan emosinya. Dengan begitu kompetensi mempengaruhi cara pandang, tindakan dan karakter seseorang. Orang yang memiliki kompetensi dapat menggunakan pemikiran intelektual dan emosinya sesuai dengan yang dibutuhkan pekerjaan, sehingga orang tersebut dapat berprestasi unggul dalam bekerja.

Satuan Polisi Pamong Praja Kota Pontianak mempunyai fungsi dan peran strategis di masyarakat di dalam pembangunan dan pertumbuhan perekonomian daerah. Hal ini karena apabila rencana srtategis dari Satuan Polisi Pamong Praja Kota 
Pontianak yang telah ditetapkan dapat berjalan dan berhasil dengan baik maka akan berdampak secara luas terhadap pembangunan di Kota Pontianak. Untuk mencapai itu semua maka sumber daya manusia yang dimiliki oleh Satuan Polisi Pamong Praja Kota Pontianak harus memiliki kompetensi yang sesuai dengan tujuan, visi dan misi organisasi, dengan harapan agar kinerja dari sumber daya manusia juga akan meningkat.

Adapun tujuan dari penelitian ini adalah untuk mengetahui pengaruh kompetensi terhadap kinerja pegawai Satuan Polisi Pamong Praja Kota Pontianak.

\section{LANDASAN TEORI}

Umar (2004), Manajemen Sumber Daya Manusia (MSDM) merupakan bagian dari manajemen keorganisasian yang memfokuskan diri pada unsur sumber daya manusia. Dessler (1997), Manajemen Sumber Daya Manusia (MSDM) adalah apa yang dilakukan oleh para manajer. Suradji (2003), Manajemen Kepegawaian Negara adalah proses dan prosedur tertentu di bidang kepegawaian yang mencakup kegiatan-kegiatan penerimaan, penempatan, penggajian, promosi, penilaian kinerja dan pemberhentian Pegawai Negeri, di lingkungan instansi Pemerintah.

Kinerja atau prestasi kerja berasal dari kata job performance atau actual performance yaitu prestasi kerja sesungguhnya yang dicapai oleh seseorang dalam melaksanakan tugas sesuai dengan tanggung jawab yang diberikan kepadanya (Mangkunegara, 2000). Kinerja dapat diartikan sebagai tingkat pelaksanaan tugas yang dicapai oleh seseorang dengan menggunakan kemampuan yang dimilikinya untuk mencapai tujuan (Ruky, 2001). Robbins (1996) mengemukakan bahwa prestasi kerja merupakan hasil evaluasi terhadap pekerjaan yang dilakukan dibandingkan dengan kriteria yang telah ditetapkan.

Umar (2002), kompetensi (Competence) adalah keterampilan atau pengetahuan yang dimiliki oleh para karyawan untuk melakukan pelayanan. Robbins (2003), kemampuan adalah suatu kapasitas individu untuk mengerjakan berbagai tugas dalam suatu pekerjaan. Prihadi (2004), competence dan competency secara umum, dalam kamus bahasa, kedua istilah dapat saling dipertukarkan dan bermakna "an ability to do sonething or for a task.

Penelitian Terdahulu. Hamlan Daly (2015) menyatakan ada pengaruh kompetensi, disiplin dan kompensasi terhadap kinerja pegawai Badan Pemberdayaan Perempuan Dan Keluarga Berencana Daerah Provinsi Sulawesi Tengah, hasil penelitian menunjukkan terdapat pengaruh positif dan signifikan secara parsial maupun simultan factor kompetensi, disiplin dan kompensasi terhadap kinerja pegawai Badan Pemberdayaan Perempuan dan Keluarga Berencana Daerah Provinsi Sulawesi Tengah.

Yusrizal (2015) menyatakan ada pengaruh disiplin kerja dan kompensasi terhadap kinerja pegawai pada Dinas Perindustrian Dan Perdagangan Provinsi Sumatera Barat, hasil penelitian menunjukkan terdapat pengaruh positif dan signifikan secara simultan disiplin kerja dan kompensasi terhadap kinerja pegawai pada Dinas Perindustrian dan Perdagangan Provinsi Sumatera Barat.

\section{Hipotesis}

H1: Diduga secara simultan faktor kompetensi yang berupa pengetahuan, keterampilan dan perilaku individu berpengaruh terhadap kinerja pegawai Satuan Polisi Pamong Praja Kota Pontianak.

H2: Diduga secara parsial faktor kompetensi yang berupa pengetahuan berpengaruh terhadap kinerja pegawai Satuan Polisi Pamong Praja Kota Pontianak.

H3: Diduga secara parsial faktor kompetensi yang berupa keterampilan berpengaruh terhadap kinerja pegawai Satuan Polisi Pamong Praja Kota Pontianak.

H4: Diduga secara parsial faktor kompetensi yang berupa perilaku individu berpengaruh terhadap kinerja pegawai Satuan Polisi Pamong Praja Kota Pontianak.

\section{METODE PENELITIAN}

Metode pendekatan yang digunakan dalam penelitian ini yaitu metode survey Penelitian ini dilakukan di wilayah Kota Pontianak. Populasi dalam penelitian ini adalah semua pegawai pada Satuan Polisi Pamong Praja Kota Pontianak 
sebanyak 110 (seratus sepuluh) orang dan Sampel yang diambil dalam penelitian ini berjumlah 110 orang. Pengambilan sampel dalam penelitian ini menggunakan metode Sensus, artinya semua populasi menjadi responden. Variabel bebas di penelitian ini terdiri dari 3 yaitu pengetahuan (X1), keterampilan (X2) dan perilaku individu (X3) sedangkan variabel terikat dalam penelitian ini yaitu kinerja (Y). Untuk mendapatkan data di penelitian ini dengan cara penyebaran kuesioner kepada responden sebanyak 110 Pegawai Satuan Polisi Pamong Praja Kota Pontianak yang juga sebagai sampel di penelitian ini.

Data di penelitian ini dianalisis menggunakan metode statistik deskriptif dengan menggunakan distribusi frekuensi.

\section{Gambar 1}

Kerangka Penelitian Analisis Pengaruh Kompetensi Terhadap Kinerja Pegawai Satuan Polisi Pamong Praja Kota Pontianak

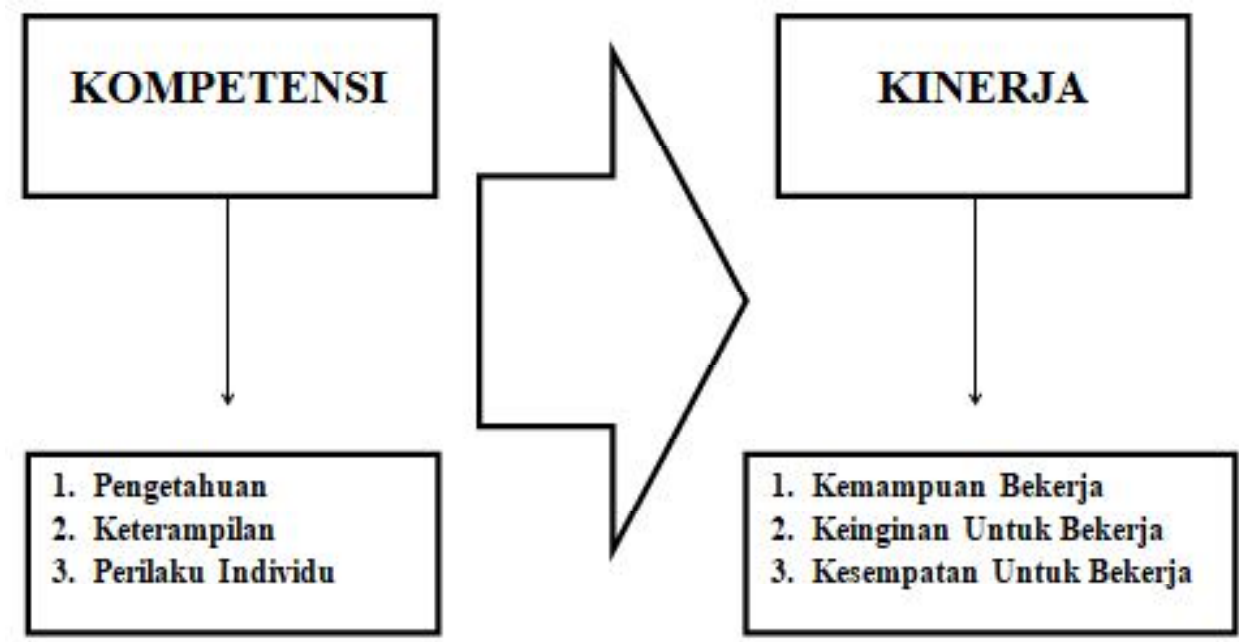

Sumber : Fink (dalam Harini, 2002)

Tabel 1

Definisi Operasional

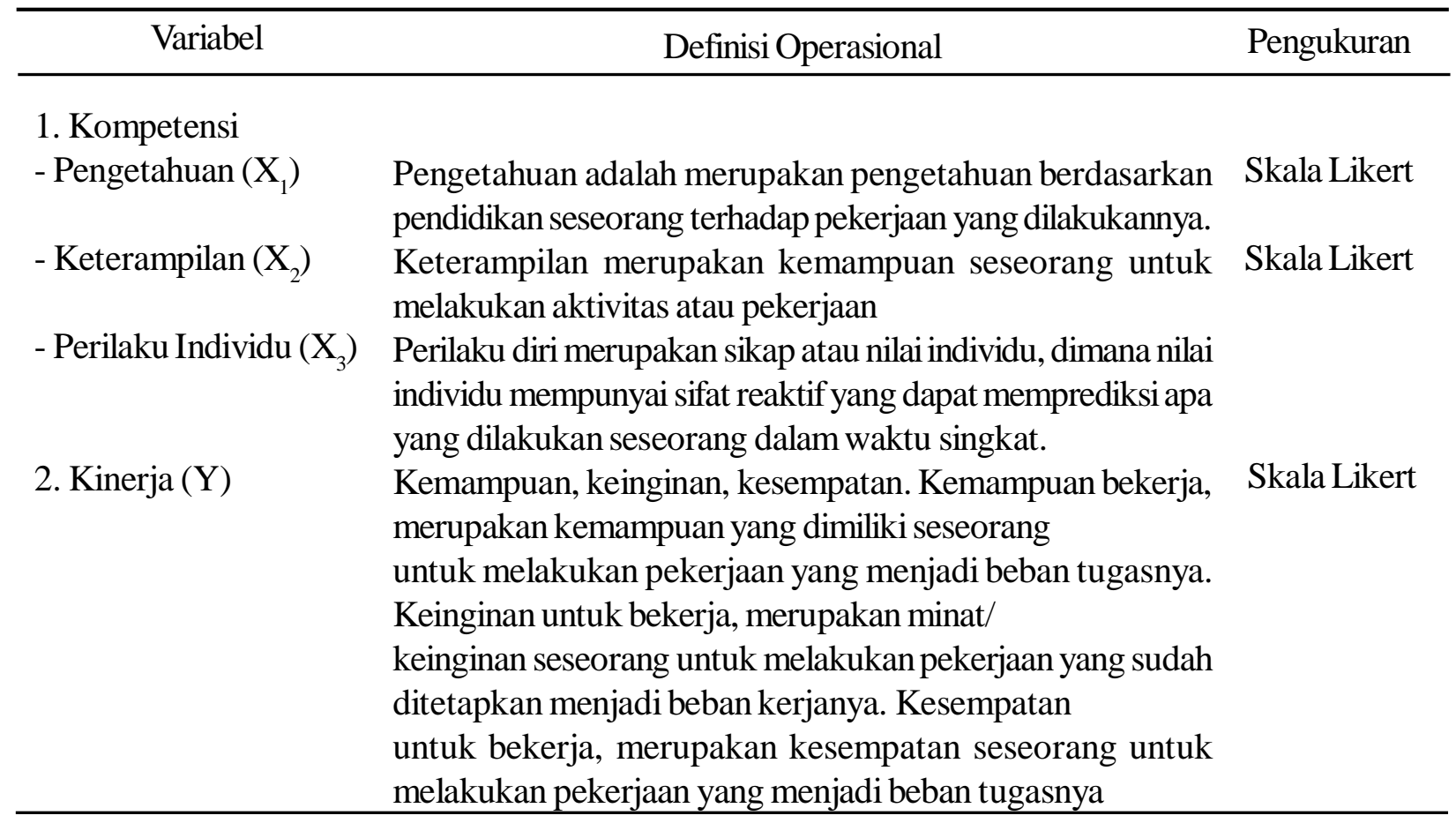




\section{HASIL PENELITIAN}

Rata-rata secara umum persentase skor nilai faktor kompetensi pada variabel pengetahuan pada peringkat 3 lebih banyak dibandingkan dengan skor nilai lainnya yakni sebesar $46,36 \%$. Rata-rata secara umum persentase skor nilai faktor kompetensi pada variabel keterampilan pada peringkat 3 lebih banyak dibandingkan dengan skor nilai lainnya yakni sebesar $55,45 \%$. Rata-rata secara umum persentase skor nilai faktor kompetensi pada variabel perilaku individu pada peringkat 4 lebih banyak dibandingkan dengan skor nilai lainnya yakni sebesar $55,45 \%$.

Rata-rata secara umum persentase skor nilai faktor kinerja pada variabel kemampuan bekerja pada peringkat 3 lebih banyak dibandingkan dengan skor nilai lainnya yakni sebesar 49,09\%. Rata-rata secara umum persentase skor nilai faktor kinerja pada variabel keinginan untuk bekerja pada peringkat 3 lebih banyak dibandingkan dengan skor nilai lainnya yakni sebesar $48,18 \%$. Rata-rata secara umum persentase skor nilai faktor kinerja pada variabel kesempatan untuk bekerja pada peringkat 3 lebih banyak dibandingkan dengan skor nilai lainnya yakni sebesar 53,64\%.
Hasil analisis menunjukkan besarnya nilai Koefisien Determinasi sebesar 0,655, maka dapat disimpulkan bahwa besarnya pengaruh dari variabel kompetensi yang berupa pengetahuan, keterampilan dan perilaku individu terhadap naik turunnya nilai atau variasi variabel kinerja adalah sebesar $65,5 \%$ sedangkan sebesar 34,5\% dipengaruhi oleh variabel lain selain variabel dalam penelitian ini.

Uji Validitas dan Reliabilitas. Dari hasil uji validitas, semua item pertanyaan memiliki nilai korelasi positif dan lebih besar dari 0,6. Hal ini berarti bahwa semua instrumen dalam penelitian ini adalah valid. Begitu pula, hasil uji reliabilitas menunjukkan semua variabel memiliki nilai koefisien Alpha Chronbach lebih besar dari 0,6, yang artinya bahwa seluruh instrumen yang digunakan dalam penelitian ini adalah reliabel.

Uji Asumsi Klasik. Sebelum dilakukan uji regresi linear berganda maka dilakukan uji asumsi klasik, dari hasil uji multikolerianitas menunjukkan bahwa tidak ada nilai VIF yang lebih dari 10 sehingga dapat dikatakan bahwa tidak ada korelasi antara variabel bebas. Selanjutnya nilai signifikansi tiap variabel terhadap absolute residual lebih dari 0,05 , artinya persamaan regresi mengalami homokedastisitas (tidak mengandung Hetero-

Tabel 2

Analisis Of Variance Pengetahuan, Keterampilan Dan Perilaku Individu Terhadap Kinerja Responden pada Satuan Polisi Pamong Praja Kota Pontianak

\begin{tabular}{lccccc}
\hline Model & $\begin{array}{c}\text { Sum Of } \\
\text { Square }\end{array}$ & Df & $\begin{array}{c}\text { Mean } \\
\text { Square }\end{array}$ & F & Sig. \\
\hline Regression & 32,982 & 3 & 10,994 & 67,043 &, $000^{\text {a }}$ \\
Residual & 17,382 & 106 & 0,164 & & \\
\hline Total & 50,364 & 109 & & & \\
\hline
\end{tabular}

Sumber : Analisis Data, 2017

Tabel 3

Analisis Uji t, Pengetahuan, Keterampilan Dan Perilaku Individu Terhadap Kinerja Responden pada Satuan Polisi Pamong Praja Kota Pontianak

\begin{tabular}{lccccc}
\hline \multirow{2}{*}{ Model } & \multicolumn{2}{c}{$\begin{array}{c}\text { Unstandardized } \\
\text { Coefficients }\end{array}$} & & $\begin{array}{c}\text { Standardized } \\
\text { Coefficients }\end{array}$ & \multirow{2}{T}{$\begin{array}{c}\mathrm{T} \\
\text { Hitung }\end{array}$} \\
\cline { 2 - 3 } & $\mathrm{B}$ & Std. Error & & Beta & \\
\hline 1 (Constant) & 0,231 & 0,251 & & 0,920 & \\
Pengetahuan & 0,622 & 0,082 & & 0,607 & 7,574 \\
Keterampilan & 0,257 & 0,081 & & 0,250 & 3,172 \\
Perilaku Individu & 0,026 & 0,071 & & 0,024 & 0,364 \\
\hline
\end{tabular}

Dependent Variabel: KINERJA

Sumber : Analisis Data, 2017 
kedastisitas) dan untuk uji normalitas data penelitian ini berdistribusi normal, dikarenakan nilai $\alpha$ lebih besar dari 0,05.

Dari hasil analisis pada Tabel 1 tersebut diketahui secara simultan nilai $\mathrm{F}$ hitung sebesar 67,043 pada tingkat signifikan 0,000a dan karena tingkat probabilitasnya 0,000 a jauh lebih kecil dari 0,05 maka model regresi ini dapat digunakan untuk memprediksi pengaruh antara variabel independent terhadap variabel dependent. Nilai F tabel 0,05 diperoleh dengan memperhatikan besarnya nilai degree of freedom (df) atau $(\mathrm{k}-1)$ dan $(\mathrm{n}-\mathrm{k})$, dimana k adalah jumlah variabel dan n adalah jumlah sampel. Nilai F tabel 0,05 adalah sebesar 2,69, sedangkan nilai $F$ hitung sebesar 67,043. Jadi nilai F hitung > nilai F tabel, yaitu 67.043>2,69, sehingga dapat disimpulkan bahwa variabel kompetensi berupa pengetahuan, keterampilan dan perilaku individu secara simultan berpengaruh nyata terhadap kinerja responden pada Satuan Polisi Pamong Praja Kota Pontianak.

Dari hasil analisis pada Tabel 2 yaitu uji parsial dapat di lihat secara parsial variabel pengetahuan memiliki nilai t hitung sebesar 7,574 dimana lebih besar dari 1,659, secara parsial variabel keterampilan memiliki nilai t hitung sebesar 3,172 dimana lebih besar dari 1,659 dan secara parsial variabel perilaku individu memiliki nilai t hitung sebesar 0,364 dimana lebih kecil dari 1,659. Jadi secara parsial variabel pengetahuan dan keterampilan memiliki pengaruh nyata terhadap kinerja, sedangkan variabel perilaku individu memiliki pengaruh yang kurang nyata terhadap kinerja responden pada Satuan Polisi Pamong Praja Kota Pontianak.

\section{PEMBAHASAN}

Sebagian besar responden menyatakan bahwa pengetahuan yang dimiliki responden dapat membantu dalam menyelesaikan pekerjaan sesuai dengan target atau standar minimal tugas yang dibebankan. Rata-rata secara umum responden memahami bahwa keterampilan yang dimiliki dapat membantu dalam menyelesaikan pekerjaan sesuai dengan target atau standar minimal tugas yang dibebankan kepada responden, responden memahami bahwa perilaku individu yang dimiliki respon- den dapat sangat membantu dalam menyelesaikan pekerjaan sesuai dengan target atau standar minimal tugas yang dibebankan kepada responden, sebagian besar responden menyatakan bahwa kemampuan bekerja untuk meyelesaikan pekerjaan yang dibebankan kapada responden dapat dilakukan sesuai dengan kemampuan yang miliki dan responden memiliki keinginan untuk melakukan pekerjaan yang dibebankan kepadanya serta responden memiliki kesempatan untuk melakukan pekerjaan sesuai dengan target atau standar minimal tugas yang dibebankan kepadanya.

Adapun kemungkinan faktor lain diluar penelitian yang dapat berpengaruh terhadap kinerja responden pada Satuan Polisi Pamong Praja Kota Pontianak yakni kompensasi, jenjang karir, motivasi serta adanya ketetapan Pemerintah tentang tata cara penilaian prestasi pegawai berdasarkan Peraturan Pemerintah Republik Indonesia Nomor 10 Tahun 1979 ditetapkan unsur-unsur pelaksanaan pekerjaan yang dinilai dalam Daftar Pelaksanaan Penilaian Pekerjaan (DP3) ada 8 (delapan) macam, yaitu kesetiaan, prestasi kerja, tanggungjawab, ketaatan, kejujuran, kerjasama, prakarsa dan kepemimpinan. Dengan demikian maka dapat disimpulkan bahwa terdapat hubungan yang kuat antara pengetahuan, keterampilan dan perilaku individu terhadap kinerja pegawai Satuan Polisi Pamong Praja Kota Pontianak.

Jika variabel pengetahuan, kompetensi dan perilaku individu dilihat secara bersamaan sebagai satu kesatuan variabel yang utuh maka variabelvariabel tersebut yang merupakan variabel kompetensi berpengaruh terhadap kinerja responden pada Satuan Polisi Pamong Praja Kota Pontianak. Kenyataan tersebut diatas sesuai dengan pernyataan responden yang menyatakan bahwa jika kompetensi yang ada cukup menunjang terciptanya kinerja terhadap organisasi yang tentunya ditunjang oleh praktek manajemen yang lebih proporsional sehingga kinerja mereka juga menjadi lebih baik. Dengan praktek manajemen yang proporsional maka tentunya memiliki dampak yang positif pada pegawai Satuan Polisi Pamong Praja Kota Pontianak. Dari kenyataan ini, kiranya manajemen sumber daya manusia menjadi vital dewasa ini dimana manajemen sumber daya manusia merupakan sistem yang terpadu mulai dari sistem 
rekruitmen, seleksi, pengembangan dan pemeliharaannya. Oleh karenanya, manajemen sumber daya manusia bisa dilihat sebagai suatu sistem sekaligus proses yang menggambarkan dinamika dan keteraturan organisasi atau perusahaan dalam peningkatan kinerja.

\section{SIMPULAN}

\section{Kesimpulan}

1. Dari analisis koefisien determinasi sebesar $65,5 \%$ maka dapat disimpulkan bahwa besarnya pengaruh dari variabel kompetensi yang berupa pengetahuan, keterampilan dan perilaku individu terhadap naik turunnya nilai atau variasi variabel kinerja adalah sebesar $65,5 \%$ sedangkan sebesar 34,5\% dipengaruhi oleh variabel lain selain variabel dalam penelitian ini.

2. Dari fungsi regresi secara umum variabel kompetensi yang berupa pengetahuan, keterampilan dan perilaku mempunyai pengaruh yang positif terhadap kinerja responden pada Satuan Polisi Pamong Praja Kota Pontianak.

3. Dari simultan kompetensi yang berupa pengetahuan, keterampilan dan perilaku individu secara simultan berpengaruh nyata terhadap kinerja responden pada Satuan Polisi Pamong Praja Kota Pontianak.

4. Dari parsial variabel kompetensi yang memiliki pengaruh nyata terhadap kinerja yakni pengetahuan dan keterampilan, sedangkan variabel perilaku individu memiliki pengaruh yang kurang nyata terhadap kinerja responden pada Satuan Polisi Pamong Praja Kota Pontianak.

\section{Saran}

1. Hendaknya Satuan Polisi Pamong Praja Kota Pontianak dapat membangun perilaku individu yang baik agar dapat membantu tercapainya peningkatan kinerja yang lebih baik lagi, dimana cara yang dapat ditempuh membangun perilaku individu adalah mengikutsertakan dalam pelatihan dan pengembangan, adanya pertemuan rutin untuk saling berbagi guna mengatasi permasalahan yang belum terselesaikan serta dapat pula dilakukan dengan bimbingan conseling terhadap pegawai yang bermasalah.

2. Hendaknya Satuan Polisi Pamong Praja Kota Pontianak dapat melakukan penilaian kinerja secara periodik selain penilaian melalui Daftar Penilaian dan Prestasi Pegawai (DP3) atau SKP.

3. Hendaknya Satuan Polisi Pamong Praja Kota Pontianak dapat memberikan penghargaan (reward) bagi pegawai yang berprestasi dan memberikan sanksi (punishment) bagi yang berkinerja kurang baik. Penghargaan dapat dilakukan melalui pemberian insentif dan kenaikan pangkat berkala secara istimewa, sedangkan sanksi dapat diberkan dengan cara tidak diberikan pekerjaan untuk sementara waktu dan proses kenaikan pangkat/golongan berkala ditunda.

\section{DAFTAR PUSTAKA}

As'ad Moh. 2001. Psikologi Industri, Edisi Keenam, Penerbit Liberty, Yogyakarta.

Agustina, Harini. 2002. Journal Riset Ekonomi Dan Manajemen. Penerbit Ikatan sarjana Ekonomi Indonesia (ISEI), Cabang Surabaya.

Bacal, Robert. 2001. Performance Management. 2002. PT. Gramedia Pustaka Utama. Jakarta

Cascio, WF, Elias M. Awad. 1991. Management Human Resources : Productivity, Quality Of Work Life, profit. Mc Graw Hill, Inc USA.

Dessler, Garry. 1997. Manajemen Sumber Daya Manusia. Jilid I. Penerbit PT. Prenhalindo, Jakarta.

Handoko, Tani. 1993. Manajemen Personalia dan Sumber Daya Manusia. Eidis Kedua, cetakan Kedua, BPFE, Yogyakarta.

Hutapea, Parulian dan Nurianna, Thoha. 2008. Kompetensi Plus, Teori, Desain, Kasus, dan Penrapan untuk HR dan Organisasi yang Dinamis. Penerbit PT. Gramedia Pustaka Utama Press. Jakarta.

Kartono. 2001. Pengantar Metodologi Riset. Penerbit CV. Mandar Maju, Bandung

John Wagner III and John R. Hollenbeck. 1995. Management of Organizational Behavior, New Jersey: Prentice-Hall Inc.

John Whitemore, Coaching for Performance. 1997. Seni Mengaerahkan untuk Mendongkrak Kinerja, terjemahan Dwi Helly Purnomo. PT. Gramedia Pustaka Utama.

John, Robert. 2001. Human Resources Management, Mc. Graw-Hill, Inc Singapore.

Nawawi, Hadari dan Martini. 1990. Metode Penelitian Sosial, Jakarta : Karunika 
Mangkunegara, AP. 2000. Manajemen Sumber Daya Manusia Perusahaan. Penerbit Rosida Bandung.

Manullang, M. 2001. Management Personalia, Ghalalia, Indonesia, Edisi ke 6, Jakarta.

Miller, L, Rankin, N and Neathy F. 2001. Competency Frameworks inUK Organization, CIP. London.

Moehardi Daniel. 2001. Metode Penelitian Sosial Ekonomi. Penerbit Bumi Aksra. Jakarta.

Ma'arif, Syamsul. 2002. Hand Out Kuliah Manjemen Kinerja. Program Magister Manajemen Universitas Tanjungpura. Pontianak.

Nangoi, Ronald. 1997. Manajemen Sumber Daya Manusia. Penerbit BPFE, Yogyakarta.

Prijono, Sutyastie. 1998. Pemberdayaan Penduduk Dan Peningkatan Kualitas Sumber Daya Manusia. PT. Citra Putra Bangsa. Jakarta.

Prawirosentono, Suyadi. 1999. Manajemen Sumber Daya Manusia (Kebijakan Kinerja Krayawan). BPFE. Yogyakarta.

Prihadi. 2004. Manajemen Sumber Daya Manusia dan Kimptensi, Penerbit PT. Toko Gunung Agung, Jakarta.

Robbins, Stephen P. 1996. Organizational Behavior, Seventh Edition, Prentice Hall.

Robbins, Stephen P. 2003. Organizational Behavior, Terjemahan Alih Bahsas Indonesia, Prentice Hall.

Rao, TV. 2001. Prestasi Penilaian Kerja Teori dan Praktek. Terjemahan Ny. L.

Mulyana, Seri Manajemen No.9, PT. Pustaka Binaman, Pressindo, Jakarta.

Ruky. 2002. Manajemen Kinerja. Penerbit Erlangga.Jakarta.

Rizieq, Rahmatullah. Ekonemetrika TMPP-L. Pontianak 2008.

Suwarno, Hadayaningrat, 1992. Pengantar Umum Pendidikan. Penerbit Rineka Cipta. Jakarta.
Soeprianto. 1996. Hubungan Industrial. Penerbit Universitas Gajah Mada, Yogyakarta.

Soerhardi, Sigit.1999. Manajemen Sumber Daya Manusia. Penerbit BPFE, Yogyakarta.

Spencer, Lyle M. Jr. and Signe M. Spencer. 1993. Competence at Work. Newyork: John Wileys and Sons.

Saydam, Gouzali. 2000. Manajemen Sumber Daya Manusia. Penerbit PT. Toko Gunung Agung, Jakarta.

Santoso, Singgih. 2000. Metode Statistik, Teori dan Aplikasi. CV. ARmico. Bandung.

Sedarmayanti. 2001. Sumberdaya Manusia dan Produktivitas Kerja, Bandung: CV. Mandar Maju.

Soehartono, Irawan. 2001. Metode Penelitian Sosial. Penerbit PT Remaja Rosdakarya. Bandung.

Siswanto. 2001. Manajemen Prestasi Kerja. Penerbit CV. Rajwali Press. Jakarta.

Sugiono. 2002. Manajemen Sumber Daya Manusia. Edisi Pertama, Asosiasi Institut Manajemen Indonesia (AIMI).

Suradji, Manajemen Pegawaian Negara, 2003. Bahan Ajaran Diklat Prajabatan Golongan III, Lembaga Administrasi Negara Republik Indonesia.

Sugiyono.2005. Metode Penelitian Bisnis.Cetakan Kedelapan. Penerbit CV. Alfabeta. Anggota Ikatan Penerbit Indonesia. Bandung.

Timpe, Dale. 1997. Seri Ilmu dan Seri Manajemen Bisnis (Jakarta: PT Elex Media Komputindo.

Umar, Husein. 2004. Sumber Daya Manusia Dalam Organisasi. Penerbit Gramedia Pustaka Utama, Jakarta.

Weigand, James. 1991. Developing Teacher Competencies. New Jersey: Prentice-Hall.

Yogi. 2004. Ekonomi Manajerial, pendekatan Analisis Praktis. Penerbit Prenada Media. Jakarta. 